\title{
Everyday Life from a Sacral Perspective. Individual Entries in Prayer Books of Intentions as Material for Social Research
}

\author{
Rafał Cekiera
}

check for updates

Citation: Cekiera, Rafał. 2021.

Everyday Life from a Sacral

Perspective. Individual Entries in Prayer Books of Intentions as Material for Social Research. Religions 12: 968. https://doi.org/10.3390/rel12110968

Academic Editor: Antony

W. Alumkal

Received: 6 October 2021

Accepted: 29 October 2021

Published: 5 November 2021

Publisher's Note: MDPI stays neutral with regard to jurisdictional claims in published maps and institutional affiliations.

Copyright: (C) 2021 by the author. Licensee MDPI, Basel, Switzerland. This article is an open access article distributed under the terms and conditions of the Creative Commons Attribution (CC BY) license (https:// creativecommons.org/licenses/by/ $4.0 /)$
Institute of Sociology, University of Silesia, Bankowa 11, 40-007 Katowice, Poland; rafal.cekiera@us.edu.pl

\begin{abstract}
This paper presents the exploratory potential of entries in prayer books of intentions displayed in places of worship and in their online counterparts-virtual boxes of intentions. By reporting the happiness, dramas, and the whole element of human existence, individual prayer intentions are extremely authentic and valuable source materials. Their analysis requires extraordinary ethical sensitivity on the part of the researcher. Based on a review of previous research explorations and my own research, a four-dimensional model of analysis is proposed, consisting of the following areas: axionormative, communitarian, communicative, and ordinary theology. It can be useful for developing analyses of such documents and also allows for comparative research. The text also discusses the limitations associated with such analyses and briefly signals the basic ethical dilemmas and possible directions for further research using prayer entries.
\end{abstract}

Keywords: prayer; intercessory prayer; prayer books of intentions; internet prayer; ordinary theology

\section{Introduction}

Prayer is amongst the basic religious practices; as W. James states, it is "the very soul and essence of religion" (James 1902, p. 464). Yet this common and significant religious activity is given relatively little attention in social analyses. In the literature, this fact is highlighted as surprising (Wuthnow 2008, p. 333), all the more so as prayer is clearly a social activity rooted in empirical experience (Swatos 1982, p. 153). Prayer takes various forms and is a peculiar tool of communication between homo orans and sacrum, between the mundane everyday life and the reality considered to be transcendent. It is a sensitive practice for many people, and it fulfills various existential functions. Prayer, understood as "the dialogical act between humanity and divinity" (Giordan 2011, p. 78), belongs to the scope of the most intimate human activities.

At least three related dimensions are given among the reasons for the perceived deficit of research on the social contexts of individual prayer practices. The first is the limited access to specific data that would allow for a qualitative study of such practices (e.g., the difficulty of accessing the content of prayers that are private, undetermined, and extra-canonical in nature). The second dimension is the "fear of touching a sacrosanct subject" (Poloma and Pendleton 1989, p. 46), i.e., a certain reserve in relation to research affecting the supernatural area, which goes beyond the possibilities of scientific descriptors. An example of this is the 20-point critique of prayer research by L. Dossey and J. Hufford, which ended with a strong appeal: "prayer need not be dishonored or degraded through research" (Dossey and Hufford 2005, p. 115). Finally, there is the third-the ethical-dimension. To analyze the practices of prayer and their content is to gain insight into people's most intimate accounts of their struggles with life, their difficulties, and happiness-the entire spectrum of human experience, communicated in the best of faith to an addressee who belongs to a different ontological order. Obviously, this raises many ethical issues and requires extreme sensitivity from the researcher and their respect for the analyzed source materials.

This paper will focus on the first of the signaled dimensions. An attempt will be made to characterize the exploratory value of entries made in prayer books of intentions 
(sometimes also simply called visitors' books) displayed in places of worship or in their online equivalents-virtual boxes of intentions. The aim of the text is to present the possibilities connected with the study of such documents and to propose a methodological scheme for their analysis.

\section{Prayer as a Subject of Social Research}

In the framework of social sciences-for the development of which research related to religiosity is extremely important-few classical authors have explicitly addressed the issue of prayer practices. In this context, the most often cited is the unfinished Mauss's book "On prayer" (Mauss 2003). As G. Giordan writes in his article "Toward a Sociology of Prayer", empirical sociological research on prayer is still in its infancy (Giordan 2011, p. 82). It is all the more noteworthy that in recent years there has been a rapidly growing interest in issues whose tangible testimony is the attempt to construct a sociological sub-discipline-the sociology of prayer (e.g., Giordan 2011; Wittberg 2013; Giordan and Woodhead 2015). This may constitute indirect evidence that there is an area of human activity that has recently undergone important and interesting transformations. Therefore, it requires performing indepth analyses and creating new theoretical approaches. This phenomenon is highlighted by the editor L. R. Olson in Journal for the Scientific Study of Religion, devoted to prayer, where the visible increase in interest in the subject is stressed (Olson 2013).

When reflecting on the category of prayer, there is a danger of mixing the supernatural order with the empirical, which in the history of science has sometimes led researchers to curious experiments (described by Spilka and Ladd 2013, among others). In order to strictly separate the two areas, it is important to properly embed the meaning of the term "prayer". The definition already cited ("the dialogical act between humanity and divinity") will be supplemented with the author's remark that "such a dialogical act can take the most diverse forms: from sacrifice to magic, from festivities to rituals, from different forms of formal recitation to mysticism" (Giordan 2011, p. 78). The communicative approach to religion, which reveals itself through various manifestations of human expression, can be enriched by emphasizing the social dimension of prayer practices: "A prayer is not just the effusion of a soul, a cry which expresses a feeling. It is a fragment of a religion. In it one can hear the echo of numberless phrases; it is a tiny piece of literature, it is the product of the accumulated efforts of men and women over generations. What we are saying is that prayer is beyond doubt a social phenomenon because the social character of religion is now sufficiently well established" (Mauss 2003, p. 33).

Social scientists have tended to analyze the practice of prayer mainly in quantitative approaches, examining, for example, the frequency of particular prayer practices or their socio-demographic determinants. At the same time, much less attention has been directed to the way people pray, what constitutes the content of their prayers, and what expectations they attach to these practices (Cadge and Daglian 2008, p. 360). Individual prayer and its goals may seem modest in manner and aspiration. However, being the quintessential religious activity, it includes all human enterprises and hopes (Spilka and Ladd 2013, p. 3). Analyses of individual prayers gain particular significance in the context of phenomena called "invisible religion" (Luckmann 1967) or "diffused religion" (Cipriani 2011), whose emanations are not always easy to grasp using traditional methodological instruments. This requires researchers to apply new means and go beyond routine research practices. By explicitly mentioning the "sociology of prayer", Cipriani stresses that various forms of prayer provide sociologists with a great opportunity to conduct various unconventional analyses (Cipriani 2011, p. 208). A good example of this would be the analysis of the entries in the prayer books of intentions available in places of worship. They are extremely authentic testimonies of everyday human experiences, interpreted in relation to the sacral order-as one scholar of this type of texts wrote, "sacredness is entangled in complicated relations with everyday life" (Kowalski 1993, p. 37). This "entanglement" present in the entries to prayer books of intentions can be considered as accessible via research and exceptionally authentic manifestation of the tension between human everyday life and the 
"sacred cosmos", of which Berger writes: "The sacred cosmos is confronted by man as an immensely powerful reality other than himself. Yet this reality addresses itself to him and locates his life in an ultimately meaningful order" $(1967$, p. 26).

\section{Notes in Prayer Books of Intentions}

A peculiar form of individual prayers are intentions recorded in books or Internet boxes of intentions, which today are individualized and improvised to a significant extent (Cadge and Daglian 2008, p. 359). They are a manifestation of different ways of life, narrations created about it, interpretation of one's own lot, perception of the world and its principles, as well as understanding one's own place in it and diversing positively and negatively valued individual experiences.

The prayer books of intentions exhibited in sacred places have their sources in classical votive books (libri miraculorum), in which miraculous events attributed to the intercession of God or the patron of a given place were recorded. Such entries had various functions: they were a testimony to the sanctity of the place and the effectiveness of intercession through its patron, raised the profile of the place of worship, and were to attract as many pilgrims as possible. They also had an exemplary aspect-they were to form and educate to holiness. This form of communication with the sacrum has a very long tradition-suffice it to say that already in the third century, Christian pilgrims in Rome left inscriptions in the catacombs "as proof of their visit, in which they begged for help from Saints Peter and Paul" (Chélini and Branthomme 1996, p. 71). Entries in votive books were once strictly standardized and governed by norms that defined the manner and formula of entry. Perhaps this is why social researchers have paid so little attention to their contents and have not used them to analyze individual prayer practices (Cadge and Daglian 2008, p. 358).

The contemporary books exhibited in places of worship differ in character from the originals and can be treated as a manifestation of "intimatization of religious life" (Kowalski 1993, p. 34). Prayer entries are increasingly rarely formal and hieratic, evolving into a polymorphous (Wojtak 2019) record of everyday experiences (e.g., Morris and Burton 2008): "Big and small problems, the whole variety of human worries and concerns, are to be found in an album which is to be a unique >correspondence $<$ with the holy patron, intermediary or steward of goods and good luck" (Kowalski 1994, p. 198). The old entries in books located in holy places resembled court entries in character, as they were written in a conventionalized form and language (e.g., Sas 2011). Today, such documents become a diverse collection of topics and a polyphonic attempt to establish contact with the sacrum. Apart from the still present testimonies of events perceived by the orants as miraculous, in the books, we find requests for various intentions, often accompanied by reflections, opinions, and postulates, manifested in different types of communication (letter, diary, poem, request, figure, etc.). Some of the entries left at places of worship are also "souvenir entries", confirming the touristic nature of visiting the site (e.g., Morris and Burton 2008). The accompanying comments or clarifications can also be an interesting testimony to the understanding of sacred space. A digital, modified variation of this sort of books are "boxes of intentions" - websites that encourage one to write down and send (publish on the website) one's own prayer intentions. They can be considered a testimony to the virtualization of religious practices, as they create a new, easily accessible tool that facilitates homo orans communication with the sacrum.

The transformations of the forms of prayer intentions signaled above had an impact on increasing the number of studies and scholarly texts devoted to them. One should start the review of the studies with Tania ap Siôn, who conducts a number of such explorations (ap Siôn 2007, 2008, 2011, 2015, 2016, 2020, and others). Many a time, in the referred analyses, she points out the fact that there is no research conducted in a comparative and systematic manner. Her contribution in this area is a proposal of a methodological matrix for the analysis of individual intercession intentions- "The ap Sion Analytic Framework for Intercessory Prayer (apSAFIP)". This is quite a general framework, suggesting a three-part study of this kind of documents: prayer intention, prayer reference, and prayer 
objective (ap Siôn 2015, p. 174). From the point of view of this text, one can distinguish the interesting and inspiring analyses concerning the influence of the environment on the form and content of the entries (ap Siôn 2018) as well as the research concerning prayer intentions recorded on the Internet (ap Siôn and Edwards 2012; ap Siôn 2015, 2016).

A lot of research explorations concern prayer texts written in hospital chapels (e.g., Hancocks and Lardner 2007; Grossoehme et al. 2010, 2011; ap Siôn and Nash 2013; Collins 2015). Describing the results of such analyses, W. Cadge and M. Daglian reconstructed the images of God hidden in the entries and noted that God is perceived as rather familiar and loving than cold or distant. As sociologists emphasize, prayer entries are also evidence of shifting notions of the God-human relationship from hierarchical models to more psychologically, emotionally, and supportive relationships, in which God provides support in giving meaning and understanding to a difficult situation, rather than leads towards specific goals (Cadge and Daglian 2008). This aspect is relatively often pointed out: God in prayer entries is rather close-with whom one can enter into an intimate relationship, who listens, expects, and wants to fulfill the recorded requests (Brown and Burton 2007, p. 51). The research of G. Schmid, who analysed 2674 intentions recorded in books from German temples, gave interesting results. Of the four areas of analysis he distinguished (addressee of a prayer, type of prayer, type of intention, and reference to groups or persons), the particularly interesting is the last area in which prayers were submitted exclusively for others (Schmied 2002). The therapeutic function of entries and the related sense of causality were indicated by L. Burton (2009) in his analyses of prayers for the dead. This function of entries was also very clearly visible in the entries from Internet prayer boxes during the first months of the COVID-19 pandemic (Cekiera 2020).

The "staggering authenticity" of such documents, which is difficult to find even in letters or diaries, is of paramount importance for social research, as highlighted by J. Tokarska-Bakir in the comment to the analyses of prayer books of intentions (TokarskaBakir 2000, pp. 117-18). These are voluntarily produced messages bearing a level of authenticity that is difficult to imagine for other social research sources. The uniqueness of this type of documents, their importance, and exploratory potential are also emphasized by linguists who study religious texts and the language of communication with the sacred (e.g., Wojtak 1998, 2000, 2019).

\section{Source Material of the Conducted Analyses}

The use of individual prayer entries proposed in this article stems from a methodological reflection based on two sources. The first is an analysis of scholarly publications in which authors report on how they use such source documents for their research. This literature was referenced in the previous subsection. The second source is the article's author's own methodological self-reflection resulting from ongoing research into individual prayer entries-both those recorded in books at the place of worship and in online intentions portals.

The prayer books of intentions analyzed by the author came from the chapel of St. Wendelin in the village of Rudzica (Silesian voivodship, southern part of Poland). Located in a charming forest ravine, the chapel, dedicated to an Iro-Scottish saint, was built in 1876. After the renovation at the turn of the 20th and 21st century, the place became increasingly visited by pilgrims and tourists. Still, it has an intimate character and is located on the sidelines of the main pilgrimage routes in Poland. In 2008, a prayer book of intentions was put on display in the chapel, and visitors were welcome to write in it. The author of the article subjected a total of 24 books to a detailed analysis. They dated from 2008 to 2014 and contained 4667 entries of various types. The research was exploratory in nature and aimed at the scientific description of the framework of meaning, within which actors orient their conduct and the positioning of this description within the framework of broader scientific theories (Giddens 1986, p. 284).

The research method was content analysis. According to the rules for this kind of procedure (Marvasti 2004; Silverman 2001), the first action was to read the entries (twice) 
and construct a categorization scheme (coding frame). Each entry was then assigned a specific code (or codes), and statistical calculations were made. During the subsequent reading of the research material, the correctness of the categorizations was checked, and the most characteristic texts were selected and used as illustrative examples. Of the total 4667 prayer entries, the largest number concerned "family life" (2827). Within this category, some subcategories were introduced to identify areas of intention that recurred relatively frequently, such as "asking for starting a family" (210), "for offspring" (130), "for correct intergenerational relationships" (126), and "for proper functioning of marriage" (107). The second most often (statistically) represented category of entries was "health" (2063). Others include "searching for the meaning of life" (541), "thanksgiving and praise" (419), "prayers of intercession for a particular person" (183), "delight in this place and its' unique atmosphere" (171), "for a good job" (114), "to get rid of an addiction" (91), "intentions for the deceased" (69), "protection during travels" (54), "global issues (e.g., world peace)" (47), "for financial improvement" (26), "for help in building a house or finding an apartment" (21), "concerning emigration of the orant or a close person" (21), "in passing the driving test" (11), "for help at the farm and good harvest" (11), and "related to the socio-political situation" (10). These explorations were complemented by the characteristics of the orants' places of residence, identified from the entries (18 different countries and 170 localities from Poland). The whole of the research was complemented by a communicative analysis, which discussed the ways of constructing prayer messages while paying suitable attention to their rich stylistic diversity and the linguistic procedures employed (sometimes pictorial). Detailed results are discussed in a separate book (Cekiera 2016).

The second source of methodological self-reflection was the analysis of online boxes of intentions and was conducted during the first months of the COVID-19 pandemic. The time frame for the selection of the research corpus was set between 1 March and 30 April 2020. This period can be considered the beginning of the development of the pandemic in Poland (the first case was reported on 4 March 2020) and, what is even more important for the analysis, the period of intense impact of coronavirus on the public awareness of Poles and the introduction of related restrictions (including radical limitation of the availability of places of worship). Entries in the three online intention boxes were analyzed: kjb24.pl/ksiega-intencji (a subpage of a website promoting the figure of St. Archangel Michael), ogrod.augustianki.pl/intencje (a subpage of the website spreading devotion to St. Rita, patron of hopeless cases) and skrzynkaintencji.pl (a website under the care of the Secular Franciscan Order in Wroclaw). A total of 2876 entries were analyzed, from which 619 entries that directly related to the COVID-19 pandemic situation were selected using keywords.

In the case of this study, it was decided to investigate prayer entries as organized narratives about an unexpected pandemic phenomenon that violently and abruptly jolted many people out of their sense of ontological security (Giddens 1991, p. 36). The aim of the first reading of the entries in the online prayer boxes was to select the appropriate research material (using the keywords: coronavirus, virus, COVID, SARS-CoV-2, epidemic, pandemic, plague, infection). The second reading allowed identifying distinctive and recurring narrative lines through which orants addressed the unexpected threat. On subsequent reading, they were divided into four main categories, named as follows: "That humanity may survive-on the threshold of the apocalypse", "Let this be a time of reflectionpandemic as metanoia", "Let this nightmare be over-for patience and peace", and "For all the people of the world-the scope of an imagined community". A recent reading of the transcripts made it possible to verify and refine the adopted typology and to select examples of texts that are characteristic of each narrative line. The outcomes of the research were published in a journal (Cekiera 2020).

The result of the research and reflection on the possibilities of interpreting this kind of research material was the four-dimensional model of analyzing individual prayer entries proposed in this article. 


\section{Potential Dimensions of Analyses of Prayer Entries}

The intentions recorded by the orants, their "correspondence with the sacrum" under various forms, can be treated as a not obvious yet sensitive barometer of changes in contemporary relations between man and supernatural reality. Intimate and private in nature, the documents give an insight into the most authentic areas of the human experience of everyday life and allow to identify the procedures of making sense of reality. In other words, they can be considered as testimonies of how man deals-to use K. Rahner's formula-with the "trials of everyday life" (Rahner 1983). This remarkable research material can be analyzed from a variety of research perspectives. A four-dimensional model will be proposed below, which may be inspiring especially for social research and may facilitate more systematic explorations.

\subsection{Axionormative Area}

This area encompasses the most obvious questions about the intentions written down by the orants: What are the topics addressed in the prayer entries? What problems do the orants address to the sacrum? What are the mentioned deficit areas? What's important to orants? How is the hierarchy of values formulated in prayer entries?

The frequency of appearance of particular categories, the order in which they are recalled, but also issues absent from the entries will allow identifying the world of values and norms internalized by orants. On the basis of the entries, it becomes possible to answer the question about the foundations and procedures of making life meaningful. In a more modest perspective, the reading and interpretation of the entries may also allow reconstructing the hot spots of subjectively perceived various tensions-for example, between the world of orants' values and the dominant social axionormative order.

This area seems to be particularly inspiring in conducting comparative research-both from a historical perspective but also from a cultural or geographical perspective.

\subsection{Community Area}

For functioning in an individualistic culture in the Late Modern Age (Giddens 1991), the issue of situating humans in relation to others becomes a fundamental problem. In this context, one of the potential consequences of prayer is clearly visible: in the communication with the Supreme Being, the orant is not a lonely existence but introduces a dense network of own social connections. This is particularly visible in the case of intercessory prayer, which does not play out in the orant-God communication dyad but has the character of a triad (with the person/group for whom the orant is praying). In such an approach, intercessory prayer becomes an interesting exploratory testimony of interpersonal relations, filtered through the sphere of sacrum (Schafer 2013, p. 37). This is particularly evident in the form of prayer analyzed here-individual, undefined, written. The very act of recording helps to activate the "community imagination" and to make people aware of the network of connections with other people or to analyze the quality of relations.

An examination of the posted prayer books of intentions provides answers to the following questions: Who do orants pray for? How broad is the community to which the help is asked for? In what way is the relationship in the triad of God-orant-other perceived? Answering these questions may allow identifying the perception, form, and scope of the subjectively understood interpersonal community together with the procedures for establishing the dichotomy of homely/stranger and us/them, also in a dimension exceeding the mortal life (attitude towards the deceased and understanding their status).

\subsection{Communication Area}

Individual prayer entries can also be looked at from the perspective of communication between the orant and sacrum. Prayers, in this sense, will be treated as manifestations of a specific interaction in which we have access only to the messages of one of the parties. Their very formulation may also prove the orant's subjective understanding of communicative 
effectiveness, as exemplified by prayers of thanksgiving for the hearing of previously made requests.

In this area, we can look for answers to the following questions: In what way the communication with sacrum is constructed? What language tools are used to formulate prayers? What is the level of formality and hieraticness of prayer entries? In what way does the form of recording (book, website) affect the shape of the prayer message?

The analysis of rituals and communication procedures used in prayer entries should allow to recognize the degree of closeness/distance between the orants and the sacrum and to identify the types of behaviors that favour communication and mediation in the human-sacrum hierarchical system. Including this area in the analysis of the prayer books of intentions also allows us to understand the specificity of textual (sometimes also textualpictorial) statements, which individual prayers are written in, and helps us to recognize the (para)literary procedures used to establish a relationship with the sacred.

\subsection{Ordinary Theology Area}

In individual prayer entries, ordinary people have the opportunity to articulate their own understanding of religious or spiritual issues (Morris and Burton 2008, p. 98). This recalls the concept of ordinary theology, which is defined by the author L. Astley as "the theological beliefs and processes of believing that find expression in the God-talk of those who have had no scholarly theological education" (Astley 2002, p. 1). It is also used by ap Siôn (2020 and others) in her analyses. This concept comes from the field of theology, but by drawing attention to the social dimension of the images of the Supreme Being, it can also be an interesting point of reference for social analysis. It is not only a matter of confronting ordinary theology with official religious doctrines but a matter of identifying the ideas behind prayer entries. Within this scope, one may seek answers to such questions, among others: What image of God (a harsh Judge? a merciful Father?) and sacrum is hidden behind prayer entries? In what way God's causality is understood? In what way the relationship between God and man is perceived? What obligations to God are attributed to man? What significance is given to a written prayer? What is the source of legitimacy of prayer entries in books and boxes of intentions?

The answers to the questions outlined above should allow for the reconstruction of imaginations of the sacred cosmos contained in the prayer entries (Berger 1967). At a different level, the interpretation of the prayer entries is possible within the continuum on a scale outlined by the dichotomy: traditional religiousness vs. "new spirituality" (Heelas 2002).

\section{Explanatory Limits and Ethical Issues}

Analyses of individual prayer entries also have their limitations and involve significant, irremediable ethical dilemmas that every researcher must confront. These studies obviously cannot be representative- they rather indicate specific processes and phenomena characteristic for a given population (people who establish written communication with the sacrum). The results cannot, therefore, be extrapolated into broader categories, although they can, of course, be an inspiration for further research, which is also representative. The exploratory limitations are connected with the nature of the data-that is, only the occasional knowledge of the socio-demographic characteristics of people who made the entries. It is not possible to fully identify the impact of the orants' imagined convention of this type of entries on how they formulate them. Interpretation of prayer entries requires from a researcher the ability to "densely read" them, which allows-as one of the researchers conducting this kind of exploration vividly puts it-" from the inscription left by a wanderer at the gates of the castle to understand something more than that he had a penknife with him" (Tokarska-Bakir 2000, p. 16).

A problem of fundamental importance is the ethical issues involved in conducting research on such documents. This issue would require a separate article-here, only the main problems will be indicated. Prayer analysis is a reading of private records, "letters to God or saints" - drawn up by people who often happen to be in a difficult or dramatic 
situation and are desperately calling for help. The entries in prayer books of intentions or Internet prayer boxes are sincere reports of human experiences, issues, deficits, struggles between people and themselves, their own fates, and the world around them - that is why it is necessary to approach them with due respect and empathy. It is absolutely necessary to unconditionally and completely anonymize the data, that is, to remove all information about the authors, but also about the people who are somehow affected by the entries (e.g., a parent asks for his son's sobriety by giving his name or initials) or other proper names (e.g., place of residence).

An irremovable question that must be answered by anyone undertaking this kind of analysis is the question of the researcher's right to read and analyze the confidential, confidant conversation between the man and his perceived sacred addressee. In the case of books displayed in public venues (or online intentions), one justification may be the openness of the entries made by the orants. When providing an inscription, people are aware that apart from the direct imaginary addressee belonging to another ontological order, the content of the entry is also available to other people and can be read by them. The entries are not secret, and it is even difficult to claim that there is any informal ban on reading them. On the contrary, there is rather a conviction that the entries are to prove in some way the "effectiveness" of a given place of cult or patron in advocating for various matters. Sometimes, the entries also contain requests to other people to pray for publicly submitted intentions.

\section{Conclusions}

The proposed model for analyzing individual prayer entries is grounded in the belief of the important and exploratory inspiring social dimension of the practice of prayer. As A. Sun writes, "prayer is made possible only through the triangular relationship among the self, society, and the divine, with society as the mediating force" (Sun 2016, p. 122). The transformations in the area of religiousness that have taken place in recent decades, which can be signaled by such notions as individualization, subjectivization, or privatization, have not only led to an increased interest of researchers in the issue of prayer but have also contributed to the loosening of some traditionally formal and hieratic forms of communication of man with the sacrum (e.g., Wojtak 2016). This makes individual prayer entries - both those traditionally made in books and those posted on online intentions sites-a research material of great and extremely promising exploratory potential.

Three directions of development of this type of research seem particularly interesting. The first is comparative research on a global scale, aiming to create broader theoretical constructs reaching beyond data acquired from a single place of worship. The second direction is connected with the progressive virtualization of various areas of human activity, including — as accelerated by the COVID-19 pandemic - the area of religious practices. The various applications or websites for recording intentions or "sending letters to God" still receive little scientific scrutiny. The third potential direction will also be an attempt to answer the question about the countercultural potential of prayer entries-to what extent they are modifications of homo sibi Deus practices, characteristic of narcissistic culture (Lasch 1991), embedded in religious contexts, and to what extent they are an example of countercultural behaviors aimed against it. Explorations conducted in each of these three directions can benefit from the analysis model proposed in this paper.

Funding: The paper prepared within the project financed with funds from the Polish National Science Centre grant "The analysis of votive books as data sources for the social research" (MINIATURA 4).

Conflicts of Interest: The author declares no conflict of interest. 


\section{References}

ap Siôn, Tania. 2007. Listening to prayers: An analysis of prayers left in a country church in rural England. Archiv für Religionspsychologie 29: 199-226. [CrossRef]

ap Siôn, Tania. 2008. Distinguishing between intention, reference, and objective in an analysis of prayer requests for health and well-being: Eavesdropping from the rural vestry. Mental Health, Religion and Culture 11: 53-65. [CrossRef]

ap Siôn, Tania. 2011. Interpreting God's activity in the public square: Accessing the ordinary theology of personal prayer. In The Public Significance of Religion. Edited by Leslie Francis and Hans-Georg Ziebertz. Leiden: Brill.

ap Siôn, Tania. 2015. Prayer requests in an English cathedral, and a new analytic framework for intercessory prayer. In $A$ sociology of Prayer, Surrey. Edited by Giuseppe Giordan and Linda Woodhead. Burlington: Ashgate.

ap Siôn, Tania. 2016. The Church of England's Pray One for Me intercessory prayer site: A virtual cathedral? Journal of Beliefs and Values 37: 78-92. [CrossRef]

ap Siôn, Tania. 2018. Lighting candles and writing prayers: Observing opportunities for spiritual practices in churches in rural Cornwall. Research in the Social Scientific Study of Religion 29: 54-74. [CrossRef]

ap Siôn, Tania. 2020. The power of place: Listening to visitors' prayers left in a shrine in rural Wales. Rural Theology 18: 87-100. [CrossRef]

ap Siôn, Tania, and Owen Edwards. 2012. Praying "Online": The Ordinary Theology of Prayer Intentions Posted on the Internet. Journal of Beliefs and Values 33: 95-109. [CrossRef]

ap Siôn, Tania, and Paul Nash. 2013. Coping through prayer: An empirical study in implicit religion concerning prayers for children in hospital. Mental Health, Religion and Culture 16: 936-52. [CrossRef]

Astley, Jeff. 2002. Ordinary Theology: Looking, Listening and Learning in Theology. Aldershot: Ashgate.

Berger, Peter L. 1967. The Sacred Canopy. Elements of a Sociological Theory of Religion. Garden City and New York: Doubleday \& Company, Inc.

Brown, Alec, and Lewis Burton. 2007. Learning from prayer requests in a rural church: An exercise in ordinary theology. Rural Theology 5: 45-52. [CrossRef]

Burton, Lewis. 2009. The dear departed: Prayers for the dead on a prayer tree in a rural English parish church. Rural Theology 7: 83-97. [CrossRef]

Cadge, Wendy, and M. Daglian. 2008. Blessings, strength, and guidance: Prayer frames in a hospital prayer book. Poetics 5-6: 358-73. [CrossRef]

Cekiera, Rafał. 2016. Zgryzoty i nadzieje. Socjologiczna analiza wpisów do ksiag wotywnych w kaplicy św. Wendelina w Rudzicy. Rudzica: Towarzystwo Miłośników Rudzicy.

Cekiera, Rafał. 2020. “Ocal ludzkość przed koronawirusem!” Analiza internetowych intencji modlitewnych w czasie pandemii. Lud 104: 213-33. [CrossRef]

Chélini, Jean, and Henry Branthomme. 1996. Drogi Boże. Historia Pielgrzymek Chrześcijańskich. Warszawa: Instytut Wydawniczy PAX.

Cipriani, Roberto. 2011. Diffused Religion and Prayer. Religions 2: 198-215. [CrossRef]

Collins, Peter. 2015. An Analysis of Hospital Chapel Prayer Requests. In A Sociology of Prayer, Surrey. Edited by Giuseppe Giordan and Linda Woodhead. Burlington: Ashgate.

Dossey, Larry, and David J. Hufford. 2005. Are prayer experiments legitimate? Twenty criticisms. Explore 1: 109-17. [CrossRef]

Giddens, Anthony. 1986. The Constitution of Society. Outline of the Theory of Structuration. Oxford: Polity Press.

Giddens, Anthony. 1991. Modernity and Self-identity: Self and Society in the Late Modern Age. Cambridge: Polity Press.

Giordan, Giuseppe. 2011. Toward a Sociology of Prayer. In Religion, Spirituality and Everyday Practice. Edited by Giuseppe Giordan and William H. Swatos Jr. Dordrecht: Springer. [CrossRef]

Giordan, Giuseppe, and Linda Woodhead, eds. 2015. A Sociology of Prayer. Burlington: Ashgate.

Grossoehme, Daniel H., Jeffrey C. Jacobson, Sian Cotton, Judith R. Ragsdale, Rhonda VanDyke, and Michael Seid. 2011. Written Prayers and Religious Coping in a Paediatric Hospital Setting. Mental Health, Religion and Culture 14: 423-32. [CrossRef]

Grossoehme, Daniel H., Rhonda VanDyke, Jeffrey C. Jacobson, Sian Cotton, Judith R. Ragsdale, and Michael Seid. 2010. Written Prayers in a Pediatric Hospital: Linguistic Analysis. Psychology of Religion and Spirituality 2: 227-33. [CrossRef]

Hancocks, Graeme, and Mary Lardner. 2007. I Say a Little Prayer for You: What Do hospital Prayers Reveal about People's Perceptions of God? Journal of Health Care Chaplaincy 8: 29-42.

Heelas, Paul L. F. 2002. The Spiritual Revolution. From "Religion" to "Spirituality". In Religions in the Modern World. Tradition and Transformation. Edited by Linda Woodhead, Paul Fletcher, Hiroko Kawanami and David J. Smith. London: Routledge.

James, William. 1902. The Varieties of Religious Experience: A Study in Human Nature. New York: Longmans, Green.

Kowalski, Piotr. 1993. Samotność i wspólnota. Inskrypcje w przestrzeniach wspótczesnego życia. Opole: Wyższa Szkoła Pedagogiczna Instytut Filologii Polskiej.

Kowalski, Piotr. 1994. Prośba do Pana Boga. Rzecz o gestach wotywnych. Wrocław: Towarzystwo Przyjaciół Polonistyki Wrocławskiej.

Lasch, Christopher. 1991. The Culture of Narcissism: American Life in an Age of Diminishing Expectations. New York: Norton.

Luckmann, Thomas. 1967. The Invisible Religion: The Problem of Religion in Modern Society. New York: Macmillan.

Marvasti, Amir B. 2004. Qualitative Research in Sociology. London: Sage.

Mauss, Marcel. 2003. On Prayer. Oxford: Berghahn. 
Morris, Norman, and Lewis Burton. 2008. The kneelers are most impressive: Reflections on reading a visitors' book. Rural Theology 6: 97-108. [CrossRef]

Olson, Laura R. 2013. From the Editor: On Prayer-and Other Manifestations of Religion in Everyday Life. Journal for the Scientific Study of Religion 52: V-VI. [CrossRef]

Poloma, Margaret M., and Brian F. Pendleton. 1989. Exploring Types of Prayer and Quality of Life: A Research Note. Review of Religious Research 1: 46-53. [CrossRef]

Rahner, Karl. 1983. The Practice of Faith: A Handbook of Contemporary Spirituality. New York: The Crossroad Publishing Company.

Sas, Maksymilian. 2011. Świat postrzegany z perspektywy "miraculum". Analiza kochawińskich zapisek o cudach. Teka Historyka 43: 108-37.

Schafer, Markus H. 2013. Close Ties, Intercessory Prayer, and Optimism Among American Adults: Locating God in the Social Support Network. Journal for the Scientific Study of Religion 52: 35-56. [CrossRef]

Schmied, Gerhard. 2002. God Images in Prayer Intention Books. Implicit Religion 5: 121-26. [CrossRef]

Silverman, David. 2001. Interpreting Qualitative Data: Methods for Analysing Talk, Text and Interaction. London: SAGE Publications.

Spilka, Bernard, and Kevin L. Ladd. 2013. The Psychology of Prayer: A Scientific Approach. New York: The Guilford Press.

Sun, Anna. 2016. A Sociological Consideration of Prayer and Agency. TDR/The Drama Review 60: 118-29. [CrossRef]

Swatos, William H., Jr. 1982. The Power of Prayer: A Prolegomenon to an Ascetical Sociology. Review of Religious Research 24: 153-63. [CrossRef]

Tokarska-Bakir, Joanna. 2000. Obraz osobliwy. Hermeneutyczna lektura źródeł etnograficznych. Wielkie opowieści. Warszawa: Universitas.

Wittberg, Patricia. 2013. Praying in Groups: Suggestions for a Sociology of Prayer. In Annual Review of the Sociology of Religion. Edited by Giuseppe Giordan and Linda Woodhead. Volume 4: Prayer in Religion and Spirituality. Leiden: Brill. [CrossRef]

Wojtak, Maria. 1998. Czy można mówić o stylu człowieczej rozmowy z Panem Bogiem? In Człowiek-Dzieło-Sacrum. Edited by Stanisław Gajda and Helmut J. Sobeczko. Opole: Uniwersytet Opolski.

Wojtak, Maria. 2000. Stylistyka modlitwy wotywnej-rekonesans. In Synchroniczne i diachroniczne aspekty badań polszczyzny. Edited by Mirosława Białoskórska. Szczecin: Uniwersytet Szczeciński.

Wojtak, Maria. 2016. Współczesne modlitewniki na tle przeobrażeń dyskursu religijnego. In Chrześcijańska kultura, myśl i edukacja. Edited by Barbara Bogołęska and Monika Worosowicz. Łódź: Wydawnictwo Uniwersytetu Łódzkiego. [CrossRef]

Wojtak, Maria. 2019. Do Boga ... , o Bogu ... , przed Bogiem ... : Gatunki przekazu religijnego w analizie filologicznej. Tarnów: Wydawnictwo Diecezji Tarnowskiej Biblos.

Wuthnow, Robert. 2008. Prayer, cognition, and culture. Poetics 36: 333-37. [CrossRef] 